\title{
Trematode metacercariae of fishes as sentinels for a changing limnological environment
}

\author{
R. Dzikowski ${ }^{1, *}$, A. Diamant ${ }^{2}$, I. Paperna ${ }^{1}$ \\ ${ }^{1}$ Department of Animal Sciences, Faculty of Agriculture, Food and Environmental Quality Sciences, \\ The Hebrew University of Jerusalem, PO Box 12, Rehovot 76100, Israel \\ ${ }^{2}$ Department of Pathobiology, Israel Oceanographic and Limnological Research Ltd., National Center for Mariculture, \\ PO Box 1212, Eilat 88112, Israel
}

\begin{abstract}
Trematode metacercaria populations infecting cichlids in Lake Kinneret (Sea of Galilee) were used as sentinels for the changing limnological environment. Parasitological data from 0+ cichlid fingerlings (Tilapia zillii, Oreochromis aureus, Sarotherodon galilaeus) were collected from the northwest shore of the lake during 1999 to 2001 and compared with data obtained from 1982 to 1984. The results show that the composition of the metacercarial populations changed significantly between the 2 samplings periods. The total number of metacercarial species found in the Kinneret cichlids was lower in 1999 to 2001 than in 1982 to 1984. Metacercariae transmitted by the snail Bulinus truncatus (Clinostomum tilapiae, Euclinostomum heterostomum, Bolbophorus levantinus and Neascus-type metacercariae - black spot and others) that were commonly found in 1982 to 1984 were absent from the fishes sampled during 1999 to 2001. The other trematode metacercariae (Centrocestus sp. and Haplorchis sp. transmitted by Melanoides tuberculata, Pygidiopsis genata transmitted by Melanopsis costata, as well as Phagicola longa, Strigeidae sp.1, an unidentified metacercaria typically found in the liver, and glochidia) increased in abundance in fishes sampled during 1999 to 2001. The calculated 'true' species richness of the habitat, extrapolated as a function of sampling effort, was significantly lower in the 1999 to 2001 versus 1982 to 1984 samples, while significantly fewer fishes needed to be sampled ('sampling effort') during 1999 to 2001 in order to reach the 'true' species richness. The higher calculated values of species richness and diversity for the 1999 to 2001 samples despite the overall decline in species number is explained by the overall increase in metacercariae prevalence.
\end{abstract}

KEY WORDS: Bioindicators · Fishes · Cichlidae · Trematode - Metacercariae - Lake Kinneret · Species richness $\cdot$ Diversity indices

Resale or republication not permitted without written consent of the publisher

\section{INTRODUCTION}

The stability of an ecosystem may be evaluated by its species richness and diversity indices (Slobodkin 1961). Extreme conditions are expected to result in the decline of the more fastidious species and, as a result, in species abundance as a whole. Species richness and diversity indices of fish-parasite communities have been employed as bioindicators for monitoring the state of aquatic ecosystems: seas, rivers and lakes (Kennedy 1997, Paperna 1997, Valtonen et al. 1997, Broeg et al. 1999, Diamant et al. 1999). Among the parasites, heteroxenous species, and helminths in par- ticular, have been suggested to be sensitive biosensors for environmental changes (D'Amelio \& Gerasi 1997, Dzikowski et al. 2003a,b). These parasites, which have multiple-host life cycles, integrate factors impacting other components of the ecosystem due to their dependence on the presence of diverse specific intermediate hosts that may represent different ecological niches.

Lake Kinneret (the Sea of Galilee) is the only natural freshwater lake in Israel. It is located in the northern part of the Syrian-African rift valley $\left(32^{\circ} 42^{\prime} 15^{\prime \prime} \mathrm{N}\right.$, $32^{\circ} 53^{\prime} 44^{\prime \prime} \mathrm{N}$ and $\left.35^{\circ} 30^{\prime} 52^{\prime \prime} \mathrm{E}, 35^{\circ} 38^{\prime} 55^{\prime \prime} \mathrm{E}\right)$. Archeological evidence gathered by Nun (1973) has shown that the annual water-level amplitude between the 
years 1100 and 1850 was less than $1.5 \mathrm{~m}$. Since 1932, after the construction of a dam at the southern exit of the Jordan River from the lake, the water level has no longer followed its natural course. As a result, seasonal and annual fluctuations in the water level have increased. Accelerated exploitation of the lake water for human use and a series of droughts resulted in an extended decline of the lake's water level from -209 to -211 m in 1950 to 1951 (Oren 1957, Serruya 1978) to -212 to $-214.87 \mathrm{~m}$ in December 2001 (State of Israel Meteorological Service, see www.israelweather.co.il/ Miflas.html), the lowest value ever recorded. The habitat most influenced by these extreme conditions was the littoral zone, which shifted its location considerably, with consequent changes in its substrate, vegetation and fauna.

In the present study we demonstrate significant changes in the composition of trematode metacercariae infecting cichlid fishes along with the recorded decline in the lake's water level. We compare metacercariae abundance in the years 1982 to $1984(-209.3$ to -211.7 $\mathrm{m})$ to that in 1999 to 2001 ( -212.0 to $-214.9 \mathrm{~m})$.

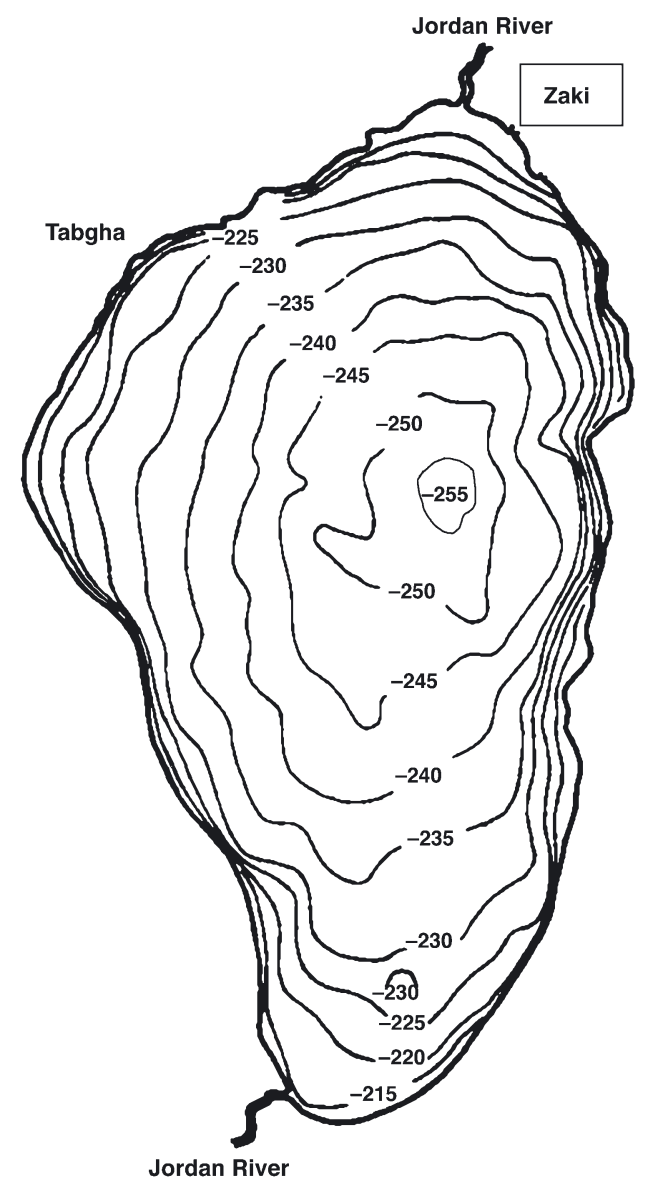

Fig. 1. Bathymetric map of Lake Kinneret (Sea of Galilee) (After Oren 1957), showing depth contours (m)
The fish family Cichlidae is represented in Lake Kinneret by 6 species, 3 of which are endemic and 3 of African origin (Steinitz 1954). Metacercariae of numerous species of trematodes have been recorded from the lake's cichlids (Paperna 1964, Yekutiel 1985, Farstey 1986, Finkelman 1988). The lake supports species of molluscs that have been shown to be first intermediate hosts (Bulinus truncatus, Melanoides tuberculata and Lymnaea auricularia: Paperna 1996), as well as piscivorous birds, which are potential final hosts of the metacercaria species infecting cichlids (Paperna \& Lengy 1963, Paperna 1996). The lake is located in the Rift Valley, a major seasonal bird migration route between northern Europe and Africa.

\section{MATERIALS AND METHODS}

Study sites and parasite-data processing. The work was carried out during 1999 to 2001 in Lake Kinneret. Sampling took place at Tabgha, which is situated on the northwest shore of the lake (Fig. 1), near the Kinneret Limnological Research Laboratory. Age 0+ cichlid fingerlings (Tilapia zillii, Oreochromis aureus, Sarotherodon galilaeus) were caught using an $18 \times 18 \mathrm{~mm}$ meshgill net and kept alive until dissection for parasitological examination (within $48 \mathrm{~h}$ of capture). Freshly prepared wet impressions of gill, heart, liver, gall bladder wall, kidney and subcutaneous muscle were examined under a stereoscope for detection and light microscope for identification of metacercariae.

These data were compared with similarly collected data from the same sampling area, from 1982 to 1984.

The following ecological indices were utilized in this study: (1) 'true' species richness extrapolated by $y=[a$ $\left.\times\left(1-\mathrm{e}^{-\mathrm{bx}}\right)\right] / \mathrm{b}$ (Walther et al. 1995); (2) species richness $S=$ no. of parasite species; (3) Margalef index of diversity $D=(S-1) / \ln (N)$ (Margalef 1958); (4) Shannon Wiener index of diversity $H^{\prime}=-\Sigma \mathrm{Pi} \times \ln (\mathrm{Pi})$ (Pielou 1978); (5) index of evenness $J=H^{\prime} / H_{\max }$, where $H_{\max }=$ $\ln (S)$ (Pielou 1978).

Statistical analysis. Parasite data were entered into a Microsoft Excel database, which was established to include data collected from each fish caught during 1982 to 1984 and 1999 to 2001, and was used to calculate the parasitological indices. Preliminary analysis of metacercarial communities of Tilapia zillii, Oreochromis aureus and Sarotherodon galilaeus showed high similarity values and were therefore pooled and analyzed as 1 entity. The calculation of 'true' species richness and its confidence limits were carried out using the SlideWrite Plus software package. The differences between species richness and diversity values, as well as abundance, were tested using 1-way 


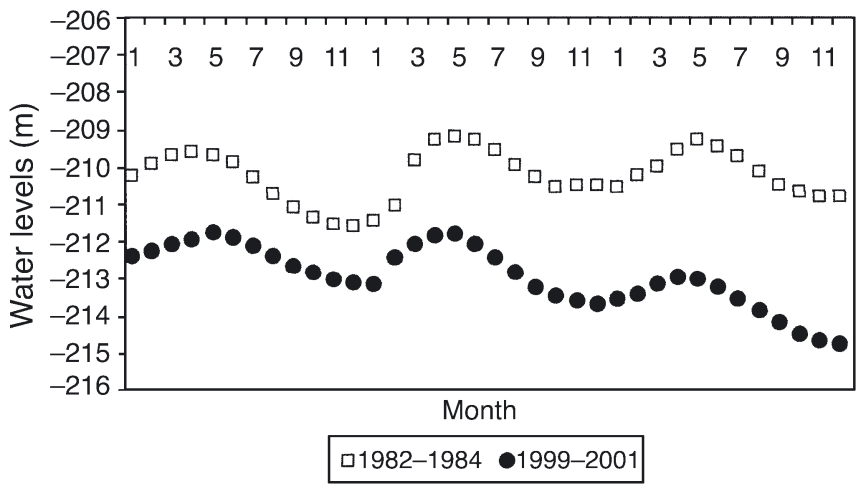

Fig. 2. Fluctuations in water levels of Lake Kinneret during 1982 to 1984 and 1999 to 2001

ANOVA. Differences in the prevalence of infection were tested using $\chi^{2}$. All statistics were carried out with the JMP statistical software package with significance levels set at $\mathrm{p}<0.05$. Host condition factor, $K=$ $100 \times$ weight/length ${ }^{3}$, was calculated according to Bolger \& Connolly (1989).

\section{RESULTS}

A succession of dry winters since 1993, together with uninterrupted exploitation of the water, resulted in a progressive decline in the water level of Lake Kinneret (Fig. 2). This in turn resulted in exposure of the littoral belt in the lake and drying-up of the flood plain in the north of the lake ('Zaki lagoon'). The decreasing water level exposed the lake's gravel beaches, and the littoral moved into the muddy zone. The exposed littoral gradually became invaded by reeds Phragmites communis and Typha angustata, and subsequently by tamarisk Tamaricetum jordanis trees.

Altogether, 9 species of metacercariae were recovered from a total of 343 fishes that were caught during 1999 to 2001. During 1982 to 1984, metacercariae of 13 trematode species were recovered from a sample of 330 fishes (Table 1). The length range of both of these fish samples was between 35 and $100 \mathrm{~mm}$, all specimens outside this length range were excluded from the analysis. The mean total length of fishes sampled during 1999 to 2001 was statistically significantly higher $(78.7 \pm 1.2 \mathrm{~mm})$ than those sampled in 1982 to $1984(60.4 \pm 1.2 \mathrm{~mm})$. As the overall differences in size did not exceed $18 \mathrm{~mm}$, no implication of fish size/age class division was assessed. The mean fish weight was $17.1 \pm 0.7 \mathrm{~g}$ during 1999 to 2001 and the condition factor $K$ was $0.32 \pm 0.002$. No data on fish weight were available from 1982 to 1984 and the condition factor could therefore not be calculated.
Prevalence of infection by the individual species of metacercariae was significantly different between the 2 periods. During 1999 to 2001, 4 species (Clinostomum tilapiae, Euclinostomum heterostomum, Bolbophorus levantinus and Neascus-type sp.) were absent from all examined cichlids, whereas in the 1982 to 1984 samples their prevalence was 7, 3.8, 48.6 and $54.6 \%$, respectively. The prevalence of Centrocestus sp., Phagicola longa, Pygidiopsis genata, Haplorchis sp., Strigeidae sp. 1 and the unidentified metacercaria found in the liver during 1999 to 2001 was 67.3, $61.4,78.7,39.3,95.3$ and $55.5 \%$. These levels were significantly higher than those of 1982 to 1984, which were $16.0,25.2,1.3,2.3,13.6$ and $0.1 \%$, respectively. Comparisons of unidentified metacercariae were not possible due to the lack of documentation for 1982 to 1984 (Table 2). The prevalence of glochidia in the gills of the fishes sampled during 1999 to 2001 was $41.7 \%$. This was significantly higher than during 1982 to 1984 , when it was only $0.17 \%$ (data not shown).

Except for the 4 species missing from the 1999 to 2001 samples, differences in the abundance of the other metacercariae were less conspicuous. The mean number of Phagicola longa metacercariae per fish during 1999 to 2001 was 1.7, significantly higher than that in 1982 to 1984 (0.5). Differences in abundance of Pygidiopsis genata and the unidentified liver metacercariae were insignificant. Infections with Centrocestus sp., Haplorchis sp. and Strigeidae sp. 1 in the 1982 to 1984 samples were not numerically quantified, therefore statistical comparisons could not be performed (Table 2).

Comparison of cichlid metacercarial 'true' species richness by sample size $\left(y=\left[a \times\left(1-\mathrm{e}^{-\mathrm{bx}}\right)\right] / b\right)$ of fishes sampled during the 2 periods showed significant differences in the curves. During 1982 to 1984, the calculated 'true' species richness of the habitat $(R)$ reached a value of 11.4. However, in order to reach this level a sample of 123 fishes was needed. This contrasts with the 1999 to 2001 curve, where only 28 fishes were

Table 1. Measurements and parameters (mean \pm SE) of cichlids sampled in Lake Kinneret during 1982-1984 and 1999-2001. Different superscript letters indicate significant differences between years at $\mathrm{p}<0.05$. $K$ : condition factor; nd: not determined; na: not applicable

\begin{tabular}{|lcc|}
\hline Parameter & $1982-1984$ & $1999-2001$ \\
\hline Total number of fishes & 330 & 343 \\
No. of Metacerceriae species & 13 & 9 \\
Avg. fish weight, $W(\mathrm{~g})$ & nd & $17.1 \pm 0.7$ \\
Avg. fish length, $L(\mathrm{~cm})$ & $60.4 \pm 1.2^{\mathrm{b}}$ & $78.7 \pm 0.9^{\mathrm{a}}$ \\
$K=W / L^{3} \times 100$ & na & $0.32 \pm 0.002$ \\
\hline
\end{tabular}


Table 2. Prevalence and abundance (mean \pm SE) of metacerceriae infecting cichlids in Lake Kinneret during 1982-1984 and 1999-2001. Further details as in Table 1. Prev.: prevalence; Abund.: abundance. Boldface emphasizes 0 prevalence of 4 species in 1999-2001 as compared to their presence in 1982-1984

\begin{tabular}{|lcccc|}
\hline \multirow{2}{*}{ Metacerceriae sp. } & \multicolumn{2}{c}{$1982-1984$} & \multicolumn{2}{c|}{$1999-2001$} \\
& Prev. & Abund. & Prev. & Abund. \\
\hline Centrocestus sp. & $16.0^{\mathrm{b}}$ & na & $67.3^{\mathrm{a}}$ & $41.6 \pm 8.4$ \\
Phagicola longa & $25.2^{\mathrm{b}}$ & $0.5 \pm 0.03^{\mathrm{b}}$ & $61.4^{\mathrm{a}}$ & $1.7 \pm 0.09^{\mathrm{a}}$ \\
Pygidiopsis genata & $1.3^{\mathrm{b}}$ & $11.3 \pm 11.2$ & $78.7^{\mathrm{a}}$ & $29.2 \pm 3.8$ \\
Haplorchis sp. & $2.3^{\mathrm{b}}$ & na & $39.3^{\mathrm{a}}$ & $3.6 \pm 7.7$ \\
Strigeidae sp. 1 & $13.6^{\mathrm{b}}$ & na & $95.3^{\mathrm{a}}$ & $31.4 \pm 5.5$ \\
Clinostomum tilapiae & $\mathbf{7}$ & $3.8 \pm 0.4$ & $\mathbf{0}$ & 0 \\
Euclinostomum heterostomum & $\mathbf{3 . 8}$ & $2.4 \pm 0.4$ & $\mathbf{0}$ & 0 \\
Bolbophorus levantinus & $\mathbf{4 8 . 6}$ & $24 \pm 1.5$ & $\mathbf{0}$ & 0 \\
Neascus sp. & $\mathbf{5 4 . 6}$ & $54 \pm 3.1$ & $\mathbf{0}$ & 0 \\
Unidentified metacerceria (liver) & $0.1^{\mathrm{b}}$ & $4.6 \pm 7.5$ & $55.5^{\mathrm{a}}$ & $10.6 \pm 1.1$ \\
Unidentified met. 1 (gill) & 0.1 & $2.5 \pm 0.5$ & nd & nd \\
Unidentified met. 2 & 2.5 & $1.3 \pm 0.1$ & nd & nd \\
Strigeidae sp. 2 (large) & 0.2 & $4 \pm 0.3$ & nd & nd \\
Unidentified met. 3 & nd & nd & 27.9 & $5.5 \pm 1.1$ \\
Unidentified met. 4 & nd & nd & 3.9 & $2.1 \pm 0.3$ \\
Unidentified met. 5 & nd & nd & 1.1 & $50.3 \pm 47.8$ \\
\hline
\end{tabular}

needed to reach 8.3 , the 'true' species richness of the habitat (Fig. 3).

Mean species richness and diversity indices of parasites (per fish) were significantly higher in 1999 to 2001 than in 1982 to 1984. Mean species richness $S$, Margalef index of diversity $D$, the Shannon Wiener index of diversity $H^{\prime}$, and the index of evenness $J$ reached values of 4.3, 0.6, 0.85 and 0.63 in 1999 to 2001, whereas in 1982 to 1984 all values were lower: 1.8, 0.1, 0.31 and 0.34 , respectively (Table 3 ).

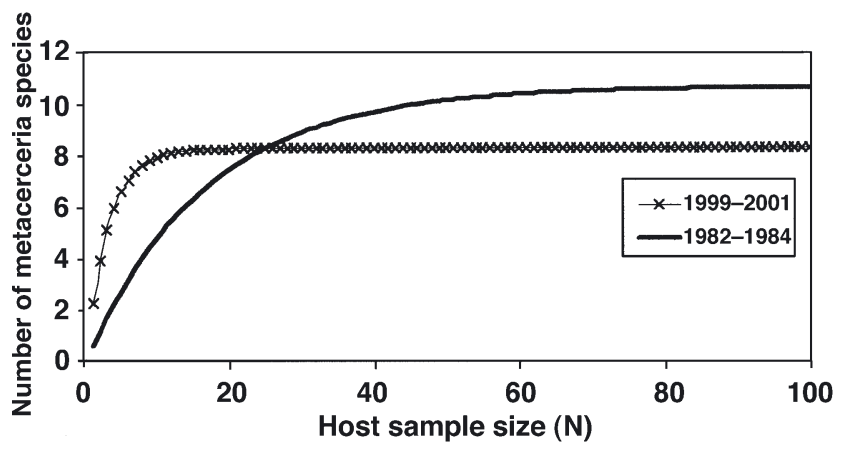

\begin{tabular}{|ccrccr|}
\hline & $\mathrm{r}^{2}$ & $R(a / b)$ & $a$ & $b$ & $c$ \\
\hline $1982-1984$ & 0.88 & 11.4 & $0.64^{\mathrm{b}}$ & $0.05^{\mathrm{b}}$ & 123 \\
$1999-2001$ & 0.6 & 8.3 & $2.65^{\mathrm{a}}$ & $0.32^{\mathrm{a}}$ & 28 \\
\hline
\end{tabular}

Fig. 3. Comparison of cichlid metacerceriae species richness by sample size $\left(y=a \times\left(1-\mathrm{e}^{-b x}\right) / b\right)$ of fishes sampled during 1982-1984 and 1999-2001 in Lake Kinneret. $r^{2}$ : regression coefficient; $\mathrm{R}(a / b)$ : calculated 'true' species richness; C: capacity, i.e. host sample size required to reach 'true' species richness

\section{DISCUSSION}

Changes in habitat conditions, which compromise the survival of the intermediate host community, are likely to interrupt the transmission of heteroxenous parasites. The different species of molluscs that serve as first intermediate hosts of trematodes in Lake Kinneret occupy different ecological niches in the littoral zone (Tchernov 1975). By definition, the littoral is an ecotone-a boundary habitat of instability between adjoining communities, where changing hydrographic conditions induce fluctuations in fauna and flora (Mozley 1954).

The results of the present study show that the composition of metacercarial populations in Lake Kinneret cichlids differs significantly in years of low (1999 to 2001) versus high (1982 to 1984) water levels. Clinostomum tilapiae, Euclinostomum heterostomum, Bolbophorus levantinus and Neascus-type metacercariae (black spot and others) that were commonly found in 1982 to 1984 were absent from the fishes sampled in 1999 to 2001. These species share a common snail intermediate host, Bulinus truncatus (Paperna \& Lengy 1963, Yekutiel 1985, Finkelman 1988, Paperna 1996). The decline in the lake water level eliminated the habitats which supported thriving populations of $B$. truncatus, notably in the Zaki lagoon (I. Paperna unpubl. data). This habitat, which was seasonally flooded, was both an important habitat of $B$. truncatus and a dense breeding and nursing ground for cichlids (Yekutiel 1985). During our studies in 1999 to 2001, the lagoon was dry and B. truncatus was not found at any of the sites where it had been common during 1982 to 1984 (Yekutiel 1985). Finkelman (1988) had already reported on the disappearance of $C$.

Table 3. Differences in metacerceriae species richness and diversity indices (mean $\pm \mathrm{SE}$ ) of cichlids sampled in Lake Kinneret during 1982-1984 and 1999-2001. S: no. of species per fish; $D$ : Margalef index of diversity $(S-1) \ln (\mathrm{N})_{i} H^{\prime}$ : Shannon Wiener index of diversity $-\Sigma \mathrm{Pi} \times \ln (\mathrm{Pi})$; $J$ : index of eveness $H^{\prime} / H_{\max }$. Further details as in Table 1

\begin{tabular}{|lrr|}
\hline Index & $1982-1984$ & $1999-2001$ \\
\hline$S$ & $1.8 \pm 0.07^{\mathrm{b}}$ & $4.3 \pm 0.07^{\mathrm{a}}$ \\
$D$ & $0.1 \pm 0.01^{\mathrm{b}}$ & $0.6 \pm 0.02^{\mathrm{a}}$ \\
$H^{\prime}$ & $0.31 \pm 0.01^{\mathrm{b}}$ & $0.85 \pm 0.02^{\mathrm{a}}$ \\
$J$ & $0.34 \pm 0.02^{\mathrm{b}}$ & $0.63 \pm 0.02^{\mathrm{a}}$ \\
\hline
\end{tabular}


tilapiae and E. heterostomum metacercariae from the cichlids of Lake Kinneret in 1987, when the lake water level declined to $-212 \mathrm{~m}$. He also failed to find $B$. truncatus in its previously known habitats. In the lake, the recession of the littoral to the mud belt did not eliminate other snails such as Melanoides tuberculata (the first intermediate host of Centrocestus sp., and Haplorchis sp.) (Farstey 1986, Paperna 1996), Melanopsis costata (the first intermediate host of Pygidiopsis genata: Dzikowski et al. unpubl. data), Bithynia hawaderiana, or even Lymnaea auricularia. The mud belt of Lake Kinneret, down to a depth of $3 \mathrm{~m}$, is the habitat of Unio semirugatus, U. terminalis and Corbicola fluminalis (Tchernov 1975). These bivalves were also observed in 1999 to 2001. Under the new environmental conditions, Melanoides tuberculata as well as Melanopsis costata may have even proliferated, which appears to be the reason for the observed increase in prevalence of metacercariae transmitted by these snails. Infections of Clinostomum complanatum (which uses $L$. auricularia as first intermediate host : Finkelman 1988) in its typical Lake Kinneret host Barbus canis remained uninterrupted (R. Dzikowski unpubl. data). The first intermediate hosts of Phagicola longa, Strigeidae sp. 1 and the unidentified metacercaria found in the liver, are unknown. Therefore we may only speculate that the increased prevalence of these species during 1999 to 2001 was related to the proliferation of their intermediate hosts. The significant increase in the prevalence of glochidia (larval stages of unionids) in the gills of fishes sampled during 1999 to 2001, compared to those sampled 1982 to 1984 suggests that this was a result of an increase in the bivalve population. Extension of the littoral into the mud belt seems to provide unionids an extended suitable substrate. The proliferation of bivalve molluscs in the upper littoral, the same habitat in which juvenile fishes spend their early life stages, increases the chances of infection with glochidia.

In looking for possible causes of increased prevalence of infection (and species richness) in metacercariae in fishes, we should, however, not overlook another potentially important factor-the observed increase in the population of piscivorous birds. These are final hosts of many trematodes that infect fishes as metacercariae, and have been attracted by the newly established dense vegetation in the drained area and waterfront.

The differences between the extrapolated exponential curves of 'true' species richness (Walther et al. 1995) constructed from the 1982 to 1984 and 1999 to 2001 data reflect the disappearance of Bulinus truncatus-transmitted trematodes in the latter samples. This model has previously been employed to examine species richness of parasite communities of marine
(D'Amelio \& Gerasi 1997, Diamant et al. 1999, Dzikowski et al. 2003a,b) and freshwater (Gelnar et al. 1997) fishes. Although the 1999 to 2001 'true' species richness of the habitat was significantly lower than in 1982 to 1984 , its curve slope was steeper, and therefore the sampling effort (number of specimens needed to reach the 'true' species richness, i.e. the curve's plateau) was significantly lower. The higher prevalence of all metacercarial species found during 1999 to 2001 (except those vectored by B. truncatus) could explain the lower sampling effort predicted by this model compared to that calculated for 1982 to 1984 .

Although the actual number of species found in Lake Kinneret cichlids declined during 1999 to 2001 due to the elimination of those vectored by Bulinus truncatus, the calculated values of mean species richness and diversity indices per fish $\left(S, D, H^{\prime}\right.$ and $\left.J\right)$ were higher than in early samples of 1982 to 1984 . These findings apparently resulted from the higher prevalence of infection among the remaining species transmitted by snails other than B. truncatus.

\section{LITERATURE CITED}

Bolger T, Connolly PL (1989) The selection of suitable indices for the measurements and analysis of fish condition. J Fish Biol 34:171-182

Broeg K, Zander S, Diamant A, Koerting W, Kruener G, Paperna I, von Westernhagen H (1999) The use of fish metabolic, pathological and parasitological indices in pollution monitoring. I. North Sea. Helgol Mar Res 53: 171-194

D'Amelio S, Gerasi L (1997) Evaluation of environmental deterioration by analysing fish parasite biodiversity and community structure. Parasitologia 39(3):237-242

Diamant A, Banet A, Paperna I, von Westernhagen H, Broeg K, Kruener G, Koerting W, Zander S (1999) The use of fish metabolic, pathological and parasitological indices in pollution monitoring. II. The Red Sea and Mediterranean. Helgol Mar Res 53:195-20

Dzikowski R, Diamant A, Paperna I (2003a) Use of fish Parasitological Species Richness indices in analyzing anthropogenically-impacted coastal marine ecosystems. Helgol Meeresunters Res (in press)

Dzikowski R, Diamant A, Paperna I (2003b) Multi-annual changes in parasite communities of the rabbitfish Siganus rivulatus (Siganidae) in the Gulf of Aqaba, Red Sea. Helgol Meeresunters Res (in press)

Farstey V (1986) Centrocestus sp. (Heterophyidae) and other trematode infections of the snail Melanoides tuberculatus (Muller, 1774) and cichlid fish in Lake Kineret. MSc thesis, Department of Zoology, Hebrew University of Jerusalem (in Hebrew with English summary)

Finkelman S (1988) Infection of Clinostomatidea in the Sea of Galilee fish. MSc thesis, Faculty of Agriculture, Hebrew University of Jerusalem (in Hebrew with English summary)

Gelnar M, Sebelova S, Dusek L, Koubkova B, Jurajda P, Zahradkova S (1997) Biodiversity of parasites in freshwater environment in relation to pollution. Parasitologia 39(3):189-200 
Kennedy CR (1997) Long-term and seasonal changes in composition and richness of intestinal helminth communities in eels Anguilla anguilla of an isolated English river. Folia Parasitol 44:27-273

Margalef R (1958) Information theory in ecology. Gen Syst 3: 36-71

Mozley A (1954) Introduction to molluscan ecology. HK Lewis London

Nun M (1973) Water levels in lake Kineret in the historical period. In: Berman $\mathrm{T}$ (ed) Symposium on warm lakes. National Council for Research and Development, Israel, p $12-73$

Oren GH (1957) Physical and chemical characteristics of Lake Tiberias. Bull Res Counc Isr Sect G Geo-Sci 11G:1-33

Paperna I (1964) The metazoan parasite fauna of Israel inland water fishes. Bamidgeh 16:3-66

Paperna I (1996) Parasites, infections and diseases of fishes in Africa - an update. Technical Paper 31. Central Institute of Freshwater Aquaculture, Food and Agriculture Organization, United Nations, Rome

Paperna I (ed) (1997) Fish parasites as indicators of environmental quality. Parassitologia 39(3):168-255

Paperna I, Lengy J (1963) Notes on a new subspecies of Bolbophrus confusus (Kraus, 1914) Dubois, 1935 (Trematoda, Diplostomatiidae), a fish transmitted bird parasite. Isr J Zool 12:171-182

Editorial responsibility: Wolfgang Körting,

Hannover, Germany
Pielou EC (1978) Population and community ecology, principles and methods. Gordon \& Breach Science Publishers, New York

Serruya C (1978) Lake Kinneret. Monogr Biol 32:123-146

Slobodkin LB (1961) Growth and regulation of animal population. Holt Rinehart \& Winston. In: Serruya C (ed) (1978) Lake Kinneret: Lake of Tiberias, Sea of Galilee. Monographiae biological, Vol 32. Junk Publ, The Hague, p 123-146

Steinitz H (1954) The distribution and evolution of the freshwater fishes of Palestine. Istanb Üniv Fen Fak Hidrobiol 1: 225-275

Tchernov E (1975) The molluscs of the Sea of Galilee. Malacologia 15(1):147-184

Valtonen ET, Holmes JC, Koskivaara M (1997) Eutrophication, pollution and fragmentation: effects on the parasite communities in roach (Rutilus rutilus) and perch (Perca fluviatilis) in four lakes in Central Finland. Can J Fish Aquat Sci 54:572-585

Walther BA, Cotgreave P, Price RD, Gregory RD, Clayton DH (1995) Sampling effort and parasite species richness. Parasitol Today 11(8):306-310

Yekutiel D (1985) Metacercarial infection of cichlid fry in Lake Kineret. MSc thesis, Department of Zoology, Hebrew University of Jerusalem (in Hebrew with English summary)

Submitted: February 10, 2003; Accepted: April 1, 2003 Proofs received from author(s): June 16, 2003 